\title{
The emotional intelligence of a group of critical-care nurses in South Africa
}

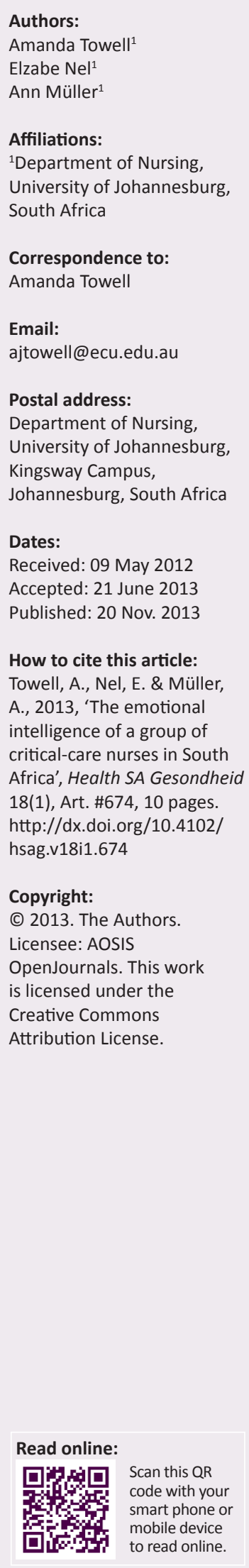

Critical-care nurses often look after three or more critically-ill patients during a shift. The workload and emotional stress can lead to disharmony between the nurse's body, mind and spirit. Nurses with a high emotional intelligence have less emotional exhaustion and psychosomatic symptoms; they enjoy better emotional health; gain more satisfaction from their actions (both at work and at home); and have improved relationships with colleagues at work. The question arises: what is the emotional intelligence of critical-care nurses? A quantitative survey was conducted. The target population was registered nurses working in critical-care units who attended the Critical Care Congress $2009(N=380)$. Data were collected with the use of the Trait Emotional Intelligence Short Form and analysed using the Statistical Package for the Social Sciences software. The sample $(n=220)$ was mainly a mature, female and professionally-experienced group of registered nurses. They held a variety of job descriptions within various critical-care units. Statistics indicated that the standard deviations were small and no aberrant aspects such as demographics skewed the findings. The conclusion was made that registered nurses who are older and that have more experience in critical care appear to have a higher range of emotional intelligence.

Kritiekesorg-verpleegkundiges verpleeg dikwels drie of meer pasiënte wat kritiek siek is, tydens een skof. Die werkslading kan tot emosionele spanning ly wat 'n wanbalans tussen die liggaam, siel en gees van die verpleegkundiges laat ontstaan. Verpleekundiges met 'n hoë emosionele intelligensie ondervind minder emosionele uitbranding en psigosomatiese symptome. Hulle toon 'n beter emosionele gesondheid, ervaar meer werks- en tuisbevrediging en het beter verhoudings met hulle kollegas. The vraag wat ontstaan is 'wat is die emosionel intelligensie van kritieksorg-verpleegkundiges?' Die toeganglike populasie $(N=380)$ was geregistreerde verpleegkundiges wat tans in die kritiek sorgeenhede werksaam was en die Critical Care Congress in 2009 bygewoon het. Die data is deur die gebruikmaking van die 'Trait Emotional Intelligence Short Form' vraelys ingesamel. Die data is statisties met behulp van die SPSS ontleed. Die populasie $(n=220)$ was hoofsaaklik n groepe volwasse, vroulike en professioneel ervare verpleegkundiges. Hulle het ' $n$ verskeidenheid van posbeskrywing in die kritieke-sorgeenhede beklee. Die statistieke het 'n minimale standaardafwyking aangetoon. Die gevolgtrekking van die studie is dat geregistreede verpleegkundiges wat ouer en meer ervaring in kritieke sorgverpleging het, 'n hoër vlak van emosionele intelligensie het

\section{Introduction}

Emotional intelligence (EI) refers to the ability to be able to identify, express, understand and regulate emotions, either negatively or positively, in oneself and in others (Matthews, Zeidner \& Roberts 2004).

In the 1990s, Salovey and Meyer proposed the first formal definition and model of the construct of emotional intelligence (Petrides, Furnham \& Mavroveli 2007). Emotional intelligence has received widespread international attention and has been linked to various disciplines such as business (Druskat \& Wolff 2001), nursing (Bellack et al. 2001), medicine (Carrothers, Gregory \& Gallagher 2000) and education (Hargreaves 2000).

Mayer, Roberts and Barside (2007) identified three theoretical models of emotional intelligence. The theoretical models are divided according to their focus, for example, if they focus on a specific ability or on more global integrations of those capacities (Mayer et al. 2007). Recent research has identified a fourth model for emotional intelligence conceptualised by Petrides and Furnham (2001), which differentiates between trait EI and ability EI. The fourth model is the trait EI model which conceptualises emotional intelligence as a trait or as typical functioning of an individual (Kirk, Schutte \& Hine 2008). The main area of application of trait EI has its focus in the clinical, educational and occupational domains. 
According to Bulmer Smith, Profetto-McGrath and Cummings (2009), nurses provide care to patients through relationships. They are responsible for contributing to the emotions that support the relationships and therefore emotional intelligence can be linked to nursing. Emotions form the foundation of nursing practice; they have an important role to play in professional relationships and patient-care decisions and can affect healthcare workers at an interpersonal level (Bulmer Smith et al. 2009). This is echoed by Freshwater and Stickley (2004), who said that without emotion it is not possible to be able to define the practice of nursing science.

The nurses in critical-care work are in a unique environment where they are expected to make critical decisions, being faced with highly-stressful situations and ethical dilemmas on a daily basis (Omdahl \& O'Donnell 2005). The physical and emotional work that is expected of these nurses is increasing through changing consumer and organisational demands, through limited resources and by increasing numbers of acutely-ill patients (Vitello-Cicciu 2003). This may lead to burnout in the nurses who work in critical care (Coates 2001; Poncet et al. 2007; Vitello-Cicciu 2003). Gibson (2004) said that it is common knowledge that nursing has high stress levels, made worse in developing countries such as South Africa due to poor salaries, staff shortages, heavy workloads and poor work environments affected by inadequate public health infrastructure.

The problem with burnout is that it can lead to the nurse displaying emotional stress, emotional labour burnout, depersonalisation, feelings of failure, stress-related illnesses, demotivation and dissatisfaction with nursing, decreased quality of care and conflicts with other staff members and patients (Coates 2001). Burnout in a critical-care nurse can have devastating consequences such as decreased wellbeing of the nurses, decreased quality of care, poor communication with families of patients and increased costs to the employer related to absenteeism and high staff turnover (Poncet et al. 2007).

Ogińska-Bulik (2005) emphasises that it is important for nurses to be able to regulate emotions in themselves and to be able to recognise emotion in others. Johnson, Batey and Holdsworth (2009) found that individuals that scored a high trait EI were better able to recognise the aspects of their personality that resulted in stress, as well as having the ability to manage these stressful emotions. Akerjordet and Severinsson (2007) highlight that it has been demonstrated in literature that people with a high emotional intelligence lead a happier, healthier and more productive professional life.

The literature on emotional intelligence and nursing identifies three main areas, namely, emotional intelligence and the nature of nursing, nursing education and nursing leadership (Bulmer Smith et al. 2009). Bulmer Smith et al. 2009 state that 'the potential uses for EI concepts in nursing practice are vast'. According to Petrides, Pita and Kokkinaki (2007), if the recently-developed and well-established taxonomy for the conceptual distinction in EI models were to be adopted and applied in nursing research, EI research would be able to advance more rapidly.

The literature on emotional intelligence and nursing demonstrated limited information about nursing studies specifically regarding emotional intelligence and critical-care nurses - and nothing from a South African critical-care nurse perspective.

\section{Problem statement}

There is a shortage of critical-care nurses and this leads to a higher load which can cause burnout in the nurses that remain. One of the effects of burnout is that the nurses may leave the critical-care environment, creating even further shortages in personnel. A negative spiral is created by burnout, emotional labour, absenteeism and eventually leaving the profession, causing more shortages and increased burnout in the nurses that remain. The question arises as to whether this negative spiral can be broken if the nurses have a higher emotional intelligence? Emotional intelligence, according to Matthews et al. (2004), will enable the nurses to identify, express, understand and regulate their emotions, either negatively or positively, in themselves and in others. Constructive self-evaluation, leading to an increase in positive feelings of competence, achievement and confidence in being able to perform well, could be improved through emotional intelligence. This may ultimately have an effect on the nurses staying in a working environment where they feel competent and confident (Görgens-Ekermans \& Brand 2012). No information is available in the literature about the emotional intelligence of critical-care nurses in South Africa, therefore the question arises: 'what is the emotional intelligence of the critical-care nurse?'

Critical-care nurses work in different critical-care speciality areas (contexts), namely, in trauma-, cardiology-, cardiothoracic-, neurology-, respiratory- and medical critical-care units. The majority of the critical-care units are in urban areas within South Africa. They can range from being basic, to specialist, to multidisciplinary units. The size of the criticalcare unit can range from small, for example four beds, to large, for example 30 beds or more. Each speciality area (context) has its specific stressors, therefore a second question arises: 'is there a significant difference in the emotional intelligence of the critical-care nurses who are working in the various critical-care contexts?'

\section{Research questions}

A summary of the two questions asked in this study is:

- What is the emotional intelligence of critical-care nurses that work in critical-care units in South Africa?

- Is there a difference in the EI score of critical-care nurses that work in the various speciality areas (contexts) with their different stressors. 


\section{Research purpose}

The purpose of this study is to identify the emotional intelligence of critical-care nurses working in different contexts of critical care.

\section{Research objectives}

This study sought to (1) identify the global emotional intelligence of critical-care nurses working in a critical-care environment and (2) identify if there is a difference in the emotional intelligence of the critical-care nurses working in the different contexts of critical care [hereafter referred to as contextual groups].

\section{Definitions of main concepts Emotional intelligence}

Emotional intelligence refers to the ability to be able to identify, express, understand and regulate emotions, either negative or positive, in oneself and in others (Matthews et al. 2004:3).

\section{Critical-care nurse}

A person registered as a nurse under section 16 of the South African Nursing Act 33 of 2005 (South Africa 2005) that has worked or is still working in a critical-care unit in South Africa.

\section{Personality traits}

'A trait is a distinguishing characteristic, feature or quality. In psychological terms personality traits are behavioral characteristics that define an individual. The unique combination of traits make us individuals, and the number of possible combinations of traits is in the millions' (definition of personality trait [Psychology Information Online n.d.]).

\section{Contextual groups}

Critical-care nurses work in different contexts namely in trauma-, cardiology-, cardio-thoracic-, neurology-, respiratory- and medical critical-care units. The majority of the critical-care units are in urban areas within South Africa. They can range from being basic, to specialist, to multidisciplinary units. The size of the critical-care unit can range from small (e.g. four beds) to large (e.g. 30 beds or more).

The context groups comprised age, whether the subjects had children, the type of basic qualification, the number of years of critical-care nursing experience, the number of subjects that had a critical-care qualification, the number of beds per critical-care unit and whether subjects were employed by the public or private healthcare sector.

\section{Operational definition}

To measure the emotional intelligence, the difference in the contextual groups and in the age and experience of the criticalcare nurses, the Trait Emotional Intelligence Short Form (TEIQue-SF) questionnaire will be used. This questionnaire was developed by Petrides and Furnham (2006). The TEIQue is a scientific measurement instrument based exclusively on trait EI theory (Trait Emotional Intelligence Research Program 2001).

\section{Null hypothesis}

The null hypothesis, $\mathrm{H} 01$ is that there is no significant difference in the emotional intelligence of the critical-care nurses in South Africa between various speciality areas and contextual groups.

\section{Theoretical framework}

The researcher will make use of the Theory for Health Promotion in Nursing (University of Johannesburg 2009), which is aimed at the promotion of health of the individual, family, group and community. Trait EI is concerned with 'cross-situational consistencies in behaviour (manifest in specific traits or behaviours such as empathy, assertiveness, optimism) as opposed to information-processing emotional intelligence, which concerns abilities' (e.g. to identify, express and label emotion) (Petrides \& Furnham 2000). Based on this, trait EI will also form part of the theoretical framework.

\section{Research method and design}

\section{Research design}

The non-experimental quantitative descriptive research design that was used during this phase was a typical descriptive survey design.

A descriptive design is used to obtain more information about characteristics within a particular field of study (Burns \& Grove 2009). This design is appropriate for this research in that it was used to gain information about the emotional intelligence of critical-care nurses in South Africa. Data were gathered from a single sample and no treatment or intervention was employed. The phenomenon of interest was the emotional intelligence of critical-care nurses.

The data obtained from surveys is primarily quantitative in nature (Polit, Beck \& Hungler 2001). Burns and Grove (2009) emphasise that this type of design is critically important for obtaining knowledge in an area in which little research has been conducted. Therefore, this research design was suited to this study as no prior research had been conducted on the emotional intelligence of critical-care nurses within South Africa (and very little for the rest of the world).

\section{Population and sampling Population}

The target population for this study was critical-care nurses working in, or who had worked in, critical-care units in South Africa.

The study population comprised critical-care nurses that attended the Critical Care Congress in August 2009, as they represented a wide range of critical-care nurses that work 
or have worked in both the private- and public healthcare sector hospitals within South Africa.

\section{Sampling method}

The sampling method used was purposive sampling. The sample population was accessible to the researcher at the Congress and the environment was non-coercive, as the subjects were away from work and had time to complete the questionnaire at their own pace. These critical-care nurses represented the majority of critical-care nurses working in critical-care units from all over South Africa. The inclusion criterion used was that the subjects were registered nurses that had worked or were still working in a critical-care unit. All potential subjects that did not meet the inclusion criterion were excluded.

\section{Data collection \\ Data collection instrument}

The data collection instrument consisted of two parts. The first part was the biographical datasheet for the subjects to complete. The information obtained from the biographical datasheet was placed into context groups. The context groups were age, critical-care experience, basic qualification, critical-care qualifications, type of critical-care unit where the subjects work, the number of beds in the critical-care unit and whether the subjects were employed by either a privateor public-health institution. The reason for collecting this information was to identify whether there was any significant difference in the emotional intelligence of the subjects placed into the various context groups.

The second part of the data instrument consisted of the data collection instrument, TEIQue-SF, based on the Trait Emotional Intelligence Long Form version 1.50 (TEIQue) developed by Petrides and Furnham (2006). The TEIQue is a scientific measurement instrument based exclusively on trait EI theory (Trait Emotional Intelligence Research Program 2001). It is recommended for research as it provides a direct gateway to trait EI theory; it aims to capture comprehensively the affective aspects of personality, a goal that gives rise to a particular factor sampling structure and a particular way of interpreting and distributing variance (Petrides, Furnham \& Mavrovelli 2007). The TEIQue is predicated on the trait EI theory and model, which conceptualises emotional intelligence as a personality trait, located at the lower levels of personality hierarchies (Pérez, Petrides \& Furnham 2005). Permission was obtained from Dr K. Petrides to use the TEIQue-SF.

The sampling domain of trait EI was derived from a content analysis of early models of emotional intelligence. Core elements were included that were common to more than a single model but peripheral elements appearing in only one conceptualisation were excluded (Petrides et al. 2007). There is an increasing body of evidence demonstrating that trait EI has incremental validity in respect of a wide range of criteria, both over the Big Five and the Giant Three Personality Frameworks (Petrides et al. 2007).
The TEIQue comprises 153 items, which provide scores on 15 subscales, four factors of broader relevance and a global trait EI score (Pérez, Petrides \& Furnham 2005). The 15 subscales are adaptability, assertiveness, emotion appraisal (self and others), emotion control, emotion expression, emotion management (others), low impulsiveness, relationships, self-esteem, self-motivation, social awareness, stress management, trait empathy, trait happiness and trait optimism. The four factors of broader relevance are wellbeing, self-control, emotionality and sociability. Scores reflect self-perceived abilities and behavioural dispositions and not cognitive abilities (Trait Emotional Intelligence Research Program 2001).

The 30-item TEIQue-SF was designed specifically as an efficient measure of global trait EI. It is composed of two items from each of the 15 subscales of the TEIQue. The items were selected for inclusion, based primarily on their correlations with the corresponding total subscale scores. This procedure was followed to ensure adequate internal consistencies and broad coverage of the sampling domain of the construct. The 30 items are responded to on a 7-point Likert scale, the scale ranging from 1 'completely disagree' to 7 'completely agree' (Petrides \& Furnham 2006). The TEIQue-SF is a standardised tool with a Cronbach's alpha of 0.88 (Petrides 2006).

\section{Data collection management}

The researcher handed out the instrument at the end of each nursing session on each of the four days of the Critical Care Congress in Sun City, South Africa in August 2009. The subjects were able to take the data collection instrument and complete it at their own pace. Collection boxes were available at three designated areas throughout the four days of the congress. The researcher emptied the collection boxes three times per day. These nurses were used as they were accessible to the researcher at the Critical Care Congress, in a non-coercive environment, were away from work and had time to complete the questionnaire.

\section{Data analysis}

A statistician from Statkon at a University in South Africa was consulted during the data analysis. SPSS version 15 for Windows was used for analysing the data. Descriptive statistics were calculated for biographical variables, mean total EQ and subscale scores. The Kolmogorov-Smirnov test for normality was used to determine whether the variance between the context groups being compared was equal or not. The next stage in exploring the data involved the use of comparison $t$-tests. The data were also analysed using a oneway analysis of variance (ANOVA) which is more flexible than the $t$-tests because it can examine data from two or more groups (Burns \& Grove 2009).

\section{Ethical considerations}

All the subjects signed a consent form. The consent form included the research purpose and objectives, an explanation of the study and what would be involved for the subject, an 
assurance of anonymity, confidentiality and privacy, a noncoercive disclaimer stating that participation was voluntary and that refusal to participate would not harm or hold any negative consequences, an option to withdraw, the details of the researcher and how to contact the researcher should a participant have any questions.

Ethical clearance was obtained from various parties (University of Johannesburg [Higher Degree and Ethics Committee], Dr Petrides and the Critical Care Society of Southern Africa) prior to conducting this research.

The ethical clearance number is AEC58/09, the Higher Degrees clearance is HDC55/2009 and clearance letters were received from the Critical Care Society and Dr Petrides.

\section{Validity and reliability Theoretical validity}

The sampling domain of trait EI was derived from a content analysis of early models of emotional intelligence. Core elements were included that were common to more than a single model but peripheral elements that appeared in only one conceptualisation were excluded (Petrides et al. 2007).

\section{Internal validity}

The researchers maintained a distance between themselves and the subjects. The data were collected in collection boxes that were placed in strategic places at the Congress venue. The data were analysed in an impartial and unprejudiced way.

\section{Measurement validity}

The Cronbach's alpha coefficient was used to examine the extent to which items in the instrument consistently measure the construct. The TEIQue-SF is a standardised tool with a Cronbach's alpha of 0.88 (Petrides 2006).

\section{External validity}

The registered nurses that attended the Congress and complied with the inclusion criteria were used as the accessible population.

\section{Reliability}

The TEIQue-SF has been applied across various subgroups and the result of the global intelligence demonstrated equivalent results (Petrides \& Furnham 2003).

\section{Results and discussion}

The accessible population consisted of $N=380$ criticalcare nurses that attended the Critical Care Congress in August 2009. The researcher distributed the data-collection instruments during the Congress and $220(n=220)$ were returned, giving a response rate of $57.5 \%$. Signed consent forms were received from all subjects $(N=220)$.
The global EI score as an overall view of the emotional intelligence of the population will be presented first and from there a more detailed breakdown of the data analysis between the context groups will be presented.

\section{Global emotional intelligence}

The curve in Figure 1 approximates a normal distribution curve. From a possible range of 210, the mean of the global EI in this study was 155.98. According to Heffernan et al. (2010), in a review of studies using the TEIQue-SF scale, no mean scores were indicated and therefore no comparison is possible. The mean of 155.98 is indicative of a higher range of emotional intelligence. The higher range scores that are achieved on an EI test indicate a potential greater ability of emotional intelligence (Beauvais et al. 2010).

\section{Biographical data of the subjects}

The subjects from the single sample were grouped together into context groups based on their answers on the biographical datasheet. The context groups are shown in Table 1 and consisted of marital status, age, whether the subjects had children, the number of dependent children, the type of basic qualification, the number of years of criticalcare nursing experience, the number of subjects that had a critical-care qualification, the number of beds per critical-care unit and whether subjects were employed by the public- or private healthcare sector.

For this study a mean was computed from all 30 items on the TEIQue-SF and a mean was then calculated for each subject. The mean TEIQue-SF for each group was calculated and then compared to identify if there was a statistically-significant difference between the various context groups.

The tests for normality found that there was no statisticallysignificant difference in the emotional intelligence of any of the various context groups based on their biographical data

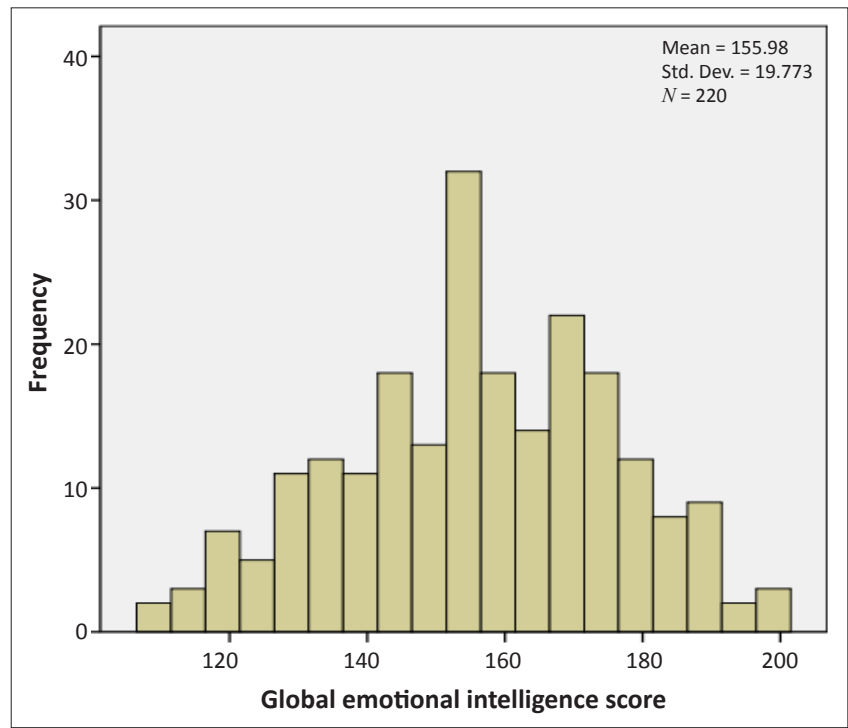

Source: Towell, Nel \& Müller 2011

FIGURE 1: Global emotional intelligence of critical-care nurses. 
as the $p$-values were all 0.200 (i.e. greater than 0.5). Therefore, no aspect related to the biographical data had a statisticallysignificant difference on the emotional intelligence, as is shown in Table 1.

The sample $(n=220)$ of this study is a dependent group, as there was one main sample on which $t$-tests were used to test if there was any significant difference between the means of the various context groups. The Levene's tests performed in this study found equal variances, which meant that the standard deviations were equal and that the homogeneity requirement was met.

The data were also analysed using a one-way ANOVA which is more flexible than the $t$-tests, since it can examine data from two or more groups (Burns \& Grove 2009). No statisticallysignificant differences were found in any of the $t$-tests or in any of the ANOVAs. In all cases the $p$-value in the $t$-tests was greater than 0.05 , therefore, the null hypothesis that there is no statistically-significant difference could be accepted.

\section{Age and emotional intelligence}

The measures of central tendency regarding the age of the subjects are shown in Figure 2. The median, mean and mode lay very close together, approximating a normal distribution curve, which shows that the sample was a mature group of critical-care nurses. The mean age is in keeping with the South African Nursing Council statistics (2009) which reported that $75 \%$ of the critical-care nurses were 40 years and older, thereby approximating the population parameter. In a study by Fariselli, Ghini and Freedman (2008), they found that there is a slight but significant increase in emotional intelligence with age.

The number of years of critical-care nursing experience of the subjects is displayed in Figure 3, which indicates that threequarters of the subjects $(75 \% ; n=179)$ had five years or more of critical-care nursing experience. This is in contrast to a study done in 2003 and 2004 by Scribante and Bhagwanjee

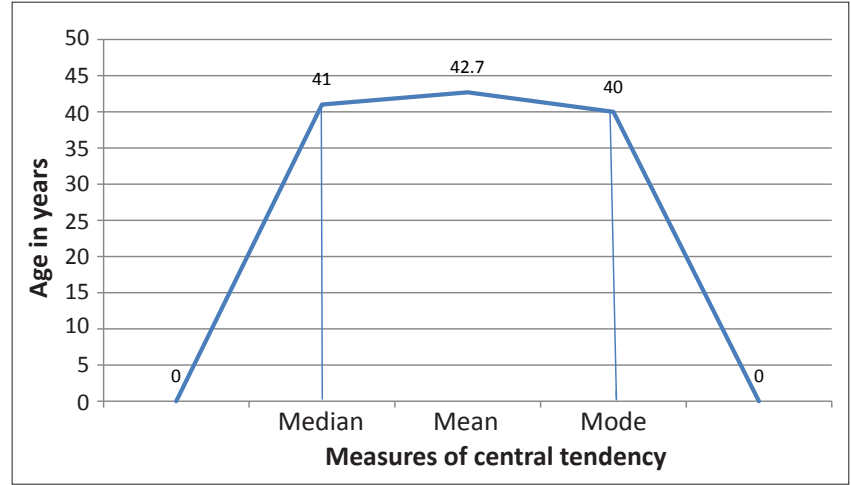

Source: Towell, Nel \& Müller 2011

FIGURE 2: Measures of central tendency.

TABLE 1: Mean Trait Emotional Intelligence Short Form scores of Context Groups.

\begin{tabular}{|c|c|c|c|c|}
\hline \multicolumn{2}{|l|}{ Mean Trait Emotional Intelligence Short Form of Context Groups } & \multicolumn{3}{|c|}{ Kolmogorov-Smirnov $\dagger$} \\
\hline & & \multirow{2}{*}{$\frac{\text { Statistic }}{0.063}$} & \multirow{2}{*}{$\begin{array}{l}\text { Df } \\
94\end{array}$} & \multirow{2}{*}{$\frac{\text { Sig. }}{0.200 *}$} \\
\hline Marital status & Single, divorced, separated or widowed & & & \\
\hline & Married or living together & 0.055 & 123 & $0.200^{*}$ \\
\hline \multirow[t]{2}{*}{ Age } & $<40$ years & 0.076 & 84 & $0.200^{*}$ \\
\hline & $>40$ years & 0.053 & 127 & $0.200^{*}$ \\
\hline \multirow[t]{2}{*}{ Whether subjects had children } & Yes & 0.051 & 164 & $0.200^{*}$ \\
\hline & No & 0.077 & 56 & $0.200^{*}$ \\
\hline \multirow[t]{3}{*}{ Number of children } & 1 child & 0.085 & 44 & $0.200^{*}$ \\
\hline & 2 children & 0.066 & 75 & $0.200^{*}$ \\
\hline & 3 or more children & 0.084 & 44 & $0.200^{*}$ \\
\hline \multirow[t]{2}{*}{ Number of dependent children } & $0-1$ child & 0.058 & 63 & $0.200^{*}$ \\
\hline & 2 or more children & 0.064 & 80 & $0.200^{*}$ \\
\hline \multirow[t]{3}{*}{ Type of basic qualification } & Bridging course & 0.126 & 23 & $0.200^{*}$ \\
\hline & 3-year diploma & 0.065 & 58 & $0.200^{*}$ \\
\hline & Degree (e.g. BCur; BSc) & 0.055 & 82 & $0.200 *$ \\
\hline \multirow[t]{2}{*}{ Number of years of critical-care nursing experience } & 5 years or less & 0.070 & 84 & $0.200^{*}$ \\
\hline & More than 5 years & 0.053 & 134 & $0.200^{*}$ \\
\hline \multirow[t]{2}{*}{ Number of subjects that were trained in critical-care nursing } & Yes & 0.052 & 156 & $0.200^{*}$ \\
\hline & No & 0.066 & 61 & $0.200^{*}$ \\
\hline \multirow[t]{2}{*}{ Number of years trained in critical-care nursing } & $<10$ years & 0.082 & 75 & $0.200^{*}$ \\
\hline & $>10$ years & 0.070 & 67 & $0.200^{*}$ \\
\hline \multirow[t]{5}{*}{ Number of beds per critical-care unit } & $<6$ beds & 0.088 & 34 & $0.200 *$ \\
\hline & $7-12$ beds & 0.080 & 86 & $0.200^{*}$ \\
\hline & $13-15$ beds & 0.092 & 30 & $0.200^{*}$ \\
\hline & $16-20$ beds & 0.106 & 25 & $0.200^{*}$ \\
\hline & $>20$ beds & 0.099 & 27 & $0.200 *$ \\
\hline \multirow[t]{2}{*}{ Employed by } & Private healthcare industry & 0.051 & 138 & $0.200 *$ \\
\hline & Public healthcare industry & 0.094 & 64 & $0.200 *$ \\
\hline
\end{tabular}

Source: Towell, Nel \& Müller 2011

$\dagger$, Lilliefors Significance Correction; Df, Degrees of freedom.

${ }^{*} p>0.05$ 
(2007) that listed $42.8 \%$ of critical-care nurses as having 0-5 years of experience; $28.7 \%$ as having more than $5-10$ years of experience; the groups with 10-15 and 15-20 years of experience both representing 16.1\%; and the smallest group comprising critical-care nurses with 20 or more years of critical-care experience. Critical-care nurses who are older and have more experience in critical-care appear to have a higher range of emotional intelligence. This was confirmed in a study by Shipley, Jackson \& Segrest (2010), where emotional intelligence was associated significantly with work experience but not with age.

\section{Number of beds per critical-care unit}

The number of critical-care beds in a hospital in South Africa should be $2 \%-8 \%$ of the total number of beds. It is advised that these beds be grouped together in units of 8-12 beds for convenient management (South African Society of Anaesthesiologists 2006). A regional hospital should have a minimum of a 6-bed high-care facility, a provincial tertiary hospital should have 8-12 critical-care beds and the minimum for a national referral centre hospital is 12 beds, with an ideal of 20 beds (Ikematsu \& Williams 2008). It is clear from Figure 4 that the majority of subjects worked in average to large critical-care units.

\section{Type of critical-care unit}

The discipline of the critical-care unit the subjects $(n=220)$ worked in or had experience in is displayed in Figure 5. Critical-care nurses in South Africa often work overtime or agency and sessional work in other units and this may lead to their having more than one area of expertise, as evidenced by the total number of responses $(n=353)$ being in excess of the number of respondents $(n=220)$.

The only information available regarding the type of criticalcare units in South Africa is whether the unit is open or closed. The ideal critical-care unit is a closed unit which is run by an intensivist who is responsible for taking the lead in developing and implementing guidelines and protocols and for developing a team approach to critical care. An open unit has no medical director and any doctor can admit, treat and discharge patients to and from the unit. It also has a nursing manager (Scribante \& Bhagwanjee 2007). Most of the critical-care units in South Africa (71\%) are open units, only $4 \%$ are private units and $72 \%$ of the public units are closed (Bhagwanjee \& Scribante 2008).

\section{General discussion and conclusion}

The subjects were mainly a mature and professionallyexperienced group of critical-care nurses. They were predominantly women with children and worked across a variety of critical-care units in South Africa. They held a variety of job descriptions in both the private- and public health sector.

In all context groups, the $p$-values in the $t$-tests were $>$ 0.05 , which means that the null hypothesis that there is no

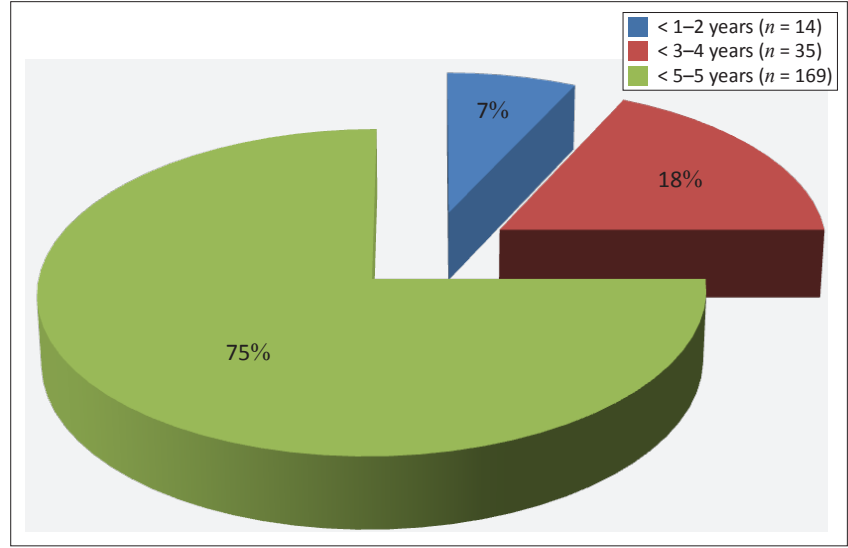

Source: Towell, Nel \& Müller 2011

FIGURE 3: Number of years of critical-care nursing experience $(n=218)$.

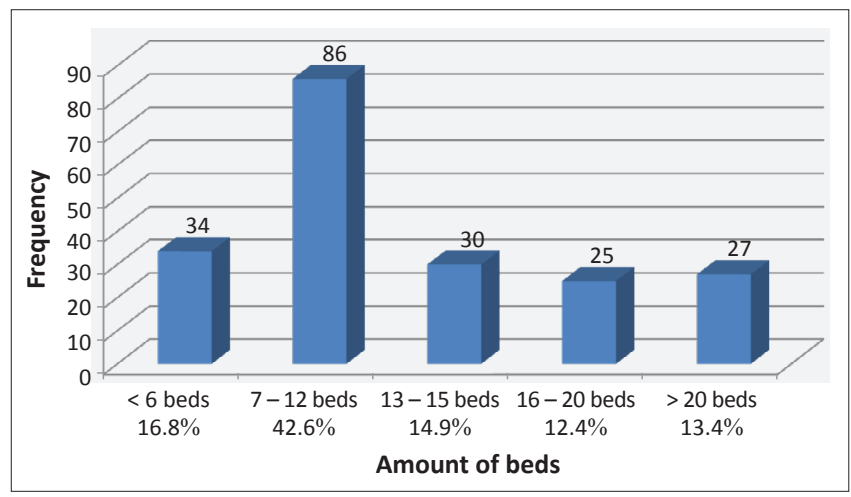

Source: Towell, Nel \& Müller 2011

FIGURE 4: Number of beds per critical-care unit $(n=202)$.

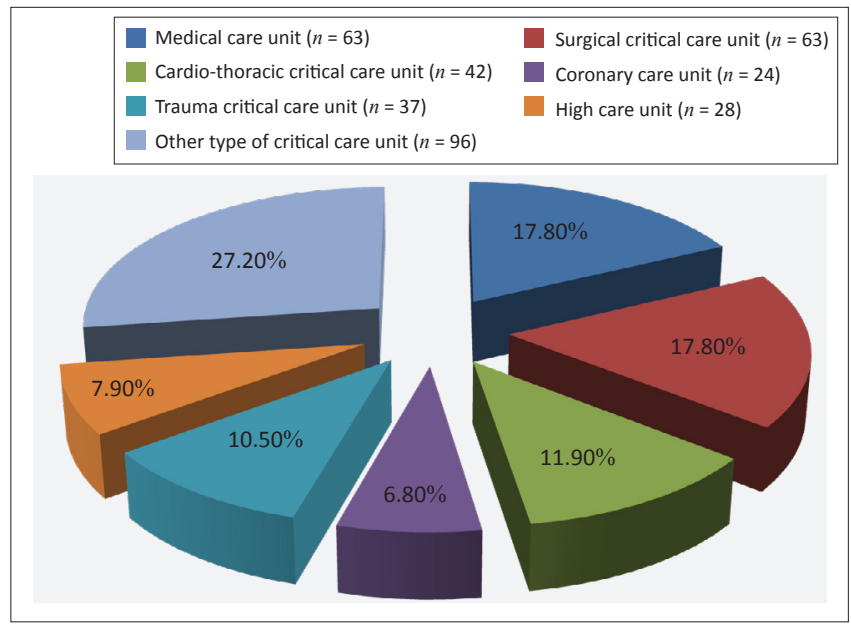

Source: Towell, Nel \& Müller 2011

FIGURE 5: Type of critical-care unit.

statistically-significant difference between the emotional intelligence of professional critical-care nurses in South Africa in the various context groups is accepted. The EI mean score of 155.98 is indicative of a higher range of emotional intelligence. This is supported by Beauvais et al. (2010), who reported that the higher range scores achieved on an EI test indicate a potential greater ability of emotional intelligence.

The context groups were homogeneous statistically and could be compared based on the Levene's tests which found equal 
variances. This was also confirmed in the tests of normality when compared at the level of means, in that the trend of no significance was observed.

The global health labour market is similar to that of other skilled professionals in that the flow of health professionals across borders is increasing. The out-migration of Africa's skilled health professionals to developed countries is facilitated by the portability of their qualifications and skills and these professionals are in increasing demand. This is posing a serious challenge in health systems in Africa (Pillay 2007). According to Chelala (2013) the WHO estimate that 23000 healthcare professionals emigrate from Africa annually. It is estimated that $6 \%$ of the United Kingdom's health professionals are South African and in total there are approximately 23407 South African medical professionals working in the United Kingdom, United States of America, Canada, New Zealand and Australia (OECD 2003). The situation is also similar for nurses - it is estimated that 9000 South African nurses are working internationally (OECD 2003).

Within critical care there is a major crisis regarding the availability of critical-care nurses, which is made worse by the high rate of loss of nurses to other countries (Ikematsu \& Williams 2008).

Analysis of the South African Nursing Council data between the period 1998-2006 shows that the population of the critical-care nurse ratio has remained unchanged, despite the production of approximately 18000 nurses during these years, suggesting that nurses are being lost from the system as a whole (Pillay 2009). There is an overwhelming majority of nurses that are planning to leave their current positions, therefore just increasing the production of nurses will not address the issue, as nurses will continue to leave the system due to dissatisfaction with their place of work (Pillay 2009). Emotional intelligence may play a role in the retention of nursing staff and patient outcomes (Kooker, Shoultz \& Codier 2007). Görgens-Ekermans and Brand (2012) state in their study that it is probable that emotional intelligence has a moderating effect on the stress-burnout relationship. Emotional intelligence is a skill that needs to be investigated further and given credibility in nursing as it has potential benefits to both patient care and staff welfare (McQueen 2004).

The loss of experienced nurses results in decreased competence within the organisation, a lack of continuity and the loss of institutional memory, all of which have an effect on the effectiveness and efficiency of a health organisation (Holmström \& Elf 2004). It also has economic implications in that knowledge production is decreased and investment in training is lost, as it takes approximately R300 000 to educate a single nurse in South Africa. The loss of experienced personnel and tutors also impacts the future production of nurses as well as the mentoring of those that remain within the organisation (Pillay 2009). The loss of the young and inexperienced nurses leaves behind an ageing population of nurses, from whom the younger nurses could have benefited in terms of mentoring.

Harper and Jones-Schenk (2012) suggested from their study that 'successful staff nurses tend to have average or above average levels of EI, indicating that demonstrates skills that enable them to function well in navigating relationships in work and life'. According to Mealer, Jones and Moss (2012), some intensive-care unit nurses thrive in their difficult work environment and have the ability to be able to tolerate and manage the effects of traumatic exposure whilst continuing to deliver excellent patient care. Resilience is one of the characteristics that allow these nurses to cope with their work environment and the unique work stressors that go with it. Resilience can also be described as the ability to maintain healthy and stable psychological functioning despite exposure to extreme stressors.

\section{Limitations}

No power analysis was undertaken for this study, thus the researchers are unable to comment on the adequacy of the sample size. Simple random sampling would have been the preferred method of sampling in a quantitative study but, due to the difficulty of obtaining permission from both the private- and public healthcare sectors (Seekoe 2010), this could have influenced the feasibility of this study.

\section{Recommendations}

According to Codier et al. (2010:946), 'performance level and nursing intuition provide evidence for the importance of EI to nursing practice'. This was echoed in a study by GörgensEkermans and Brand (2012) where they found that a higher emotional intelligence is associated positively with less selfreported stress and burnout in nurses.

By providing new staff with a resilient positive role model may help in the development of coping skills, social networks and could possibly enable the new critical-care nurse to be able to be able to cope in a stressful environment (Mealer et al. 2012). According to Mealer et al. (2012:1449), 'highly resilient nurses use emotional intelligence to guide decision-making and incorporate methods such as positive refraining, critical reflection and optimism to be able to process the emotional charged atmosphere of critical care'.

Further evidence suggests that emotional intelligence training may improve emotional intelligence (Fletcher et al. 2009). Gardner (2005) found significant increases in EI scores after the implementation of a five-week EI training programme. Freshwater and Stickley (2004) suggested that, with the use of reflective learning, supportive supervision, positive mentoring and role modelling, coaching of emotional intelligence can be accomplished.

During and after nursing education programmes high attrition is generated by the structured, unhealthy and emotionally-cold environment of hospitals, combined with 
the stressful nature of nursing. This can be addressed through the development of emotional intelligence (McQueen 2004). Bulmer Smith et al. (2009), in their literature review of emotional intelligence and nursing, state that there is strong support for the explicit inclusion of EI concepts within nursing education curricula. They suggest that nursing curricula should include EI training such as reflective learning experiences, supportive supervision and mentorship, as well as the ability to model and develop empathy and emotional competency.

Jordan and Troth (2002) suggested from the findings of their study that nurses who are taught emotional management and discussion skills may be better able to deal with and to resolve conflict situations in their everyday work. An opportunity for learning effective interpersonal skills is created when conflict is approached with high levels of emotional intelligence. If conflict is handled appropriately the experience can lead to enhanced productivity in the unit (Morrison 2008).

According to Vitello-Cicciu (2002), the ability to identify emotions in oneself can be enhanced by self-reflection. Reflection in nursing practice, education and research has spread globally and the emphasis placed on development of self-awareness as a leadership strategy has contributed to this increase (Horton-Deutsch \& Sherwood 2008). This can be done by keeping an emotional reflection journal, meditating daily, using positive visualisation, using appreciative inquiry and by practising empathic listening (Vitello-Cicciu 2003).

\section{Acknowledgements Competing interests}

The authors declare that they have no financial or personal relationship(s) which may have inappropriately influenced them in writing this article.

\section{Authors' contributions}

A.T. (University of Johannesburg) completed this project for D. Cur, E.N. (University of Johannesburg) was the supervisor for the D. Cur and A.M. (University of Johannesburg) was the co-supervisor.

\section{References}

Akerjordet, K. \& Severinsson, E., 2007, 'Emotional intelligence: a review of the literature with specific focus on empirical and epistemological perspectives', Journal of Clinical Nursing 16(8), 1405-1416. http://dx.doi.org/10.1111/j.1365-2702.2006.01749.x, PMid:17655529

Bellack, J.P., Morjikian, R., Barger, S., Strachota, E., Fitzmaurice, J., Lee, A., et al., 2001, 'Developing BSN leaders for the future: the Fuld Leadership Initiative for Nursing Education (LINE)', Journal of Professional Nursing 17(1), 23-32. http://dx.doi. org/10.1053/jpnu.2001.20247, PMid:11211379

Beauvais, A.M., Brady, N, O'Shea, E.R. \& Griffin, M.T., 2010, 'Emotional intelligence and nursing performance among nursing students', Nurse Education Today 31(4), 396-401. http://dx.doi.org/10.1016/j.nedt.2010.07.013, PMid:20739106

Bhagwanjee, S. \& Scribante, J., 2008, 'National audit of critical care resources in South Africa. How long before we act?', South African Medical Journal of Critical Care 24(1), 4-6.

Bulmer Smith, K., Profetto-McGrath, J. \& Cummings, G.G., 2009, 'Emotional intelligence and nursing: an integrative literature review', International Journal of Nursing Studies 46(12), 1624-1636. http://dx.doi.org/10.1016/j.ijnurstu.2009.05.024 PMid:19596323

Burns, N. \& Grove, S.K., 2009, The practice of nursing research: Appraisal, synthesis, and generation of evidence, 6th edn., Saunders Elsevier, St. Louis.
Carrothers, R.M., Gregory, S.W. Jr. \& Gallagher, T.J., 2000, 'Measuring emotional intelligence of medical school applicants', Academic Medicine 75(5), 456-463. http://dx.doi.org/10.1097/00001888-200005000-00016, PMid:10824770

Chelala, C., 2013, 'Brain drain worsens health care crisis in Africa', The Japan Times, viewed 29 July 2013, from http://www.japantimes.co.jp/opinion/2013/07/14/ commentary/brain-drain-worsens-health-care-crisis-in-africa/

Coates, K.J., 2001, 'Critical challenge', Nurse Week, viewed 21 April 2006, from http:// www.nurseweek.com/news/features/01-08/critical_print.html [website now merged into http://www.nurse.com]

Codier, E., Muneno, L., Franey, K. \& Matsuura, F., 2010, 'Is emotional intelligence an important concept for nursing practice?', Journal of Psychiatric and Mental Health Nursing 17(10), 940-948. http://dx.doi.org/10.1111/j.1365-2850.2010.01610.x, PMid:21121178

Druskat, V.U. \& Wolff, S.B., 2001, 'Building the emotional intelligence of groups', Harvard Business Review 79(3), 80-90. PMid:11246926

Fariselli, L., Ghini, M. \& Freedman, J., 2008, 'Age and emotional intelligence', Sixseconds, The Emotional Intelligence Network, viewed 26 July 2013, from http://www.6seconds.org/sei/media/WP_EQ_and_Age.pdf

Fletcher, I., Leadbetter, P., Curran, A., \& O'Sullivan, H., 2009, 'A pilot study assessing emotional intelligence training and communication skills with 3 rd year medical students', Patient Education and Counseling 76(3), 376-379. http://dx.doi. students', Patient Education and Counseling
org/10.1016/j.pec.2009.07.019, PMid:19674861

Freshwater, D. \& Stickley, T., 2004, 'The heart of the art: emotional intelligence in nurse education', Nursing Inquiry 11(2), 91-98. http://dx.doi.org/10.1111/j.14401800.2004.00198.x, PMid:15154888

Gardner, L., 2005, 'Emotional intelligence and occupational stress', unpublished PhD thesis, Organisational Psychology Research Unit, Swinbourne University, viewed 26 July 2013, from http//www.researchbank.swinburne.edu.au/vital/access/ services/Download/.../SOURCE2

Gibson, D., 2004, 'The gaps in the gaze in South African hospitals', Socia Science and Medicine 59(10), 2013-2024. http://dx.doi.org/10.1016/j. socscimed.2004.03.006, PMid:15351469

Görgens-Ekermans, G. \& Brand, T., 2012, 'Emotional intelligence as a moderator in the stress-burnout relationship: a questionnaire study on nurses', Journa of Clinical Nursing 21(15-16), 2275-2285. http://dx.doi.org/10.1111/j.13652702.2012.04171.x, PMid:22788561

Hargreaves, A., 2000, 'Mixed emotions: teachers' perceptions of their interactions with students', Teaching and Teacher Education 16(8), 811-826. http://dx.doi. org/10.1016/S0742-051X(00)00028-7

Harper, M.G. \& Jones-Schenk, J., 2012, 'The emotional intelligence profile of successful staff nurses', The Journal of Continuing Education in Nursing 43(8), 354-362. http://dx.doi.org/10.3928/00220124-20120615-44, PMid:22715873

Heffernan, M., Quinn Griffin, M.T., McNulty, R. \& Fitzpatrick, J.J., 2010, 'Selfcompassion and emotional intelligence in nurses', International Journal of Nursing Practice 16(4), 366-373. http://dx.doi.org/10.1111/j.1440-172X.2010.01853.x, Practice 16(4),
PMid:20649668

Holmström, P. \& Elf, M., 2004, 'Staff retention and job satisfaction at a hospital clinic - a Case study', paper presented at the 22nd International Conference of the System Dynamics Society, University of Oxford, July 25-29.

Horton-Deutsch, S. \& Sherwood, G., 2008, 'Reflection: An educational strategy to develop emotionally-competent nurse leaders', Journal of Nursing Management 16(8), 946-954. http://dx.doi.org/10.1111/j.13652834.2008.00957.x, PMid:19094107

Ikematsu, Y. \& Williams, G., 2008, Research brief: a multi-national survey of critical care nursing certification, viewed 06 July 2013, from http://www.thefreelibrary. $\mathrm{com} /$ Research+brief\%3a+a+multi-national+survey+of+critical+care+nursing... $-\mathrm{a} 0200117641$

Johnson, S.J., Batey, M. \& Holdsworth, L., 2009, 'Personality and health: The mediating role of trait emotional intelligence and work locus of control', Personality and Individual Differences 47(5), 470-475. http://dx.doi.org/10.1016/j. paid.2009.04.025

Jordan, P.J. \& Troth, A.C., 2002, 'Emotional intelligence and conflict resolution in nursing', Contemporary Nurse 13(1), 94-100. http://dx.doi.org/10.5172/ conu.13.1.94, PMid:16118974

Kirk, B.A., Schutte, N.S. \& Hine, D.W., 2008, 'Development and preliminary validation of an emotional self-efficacy scale', Personality and Individual Differences 45(5), 432-436. http://dx.doi.org/10.1016/j.paid.2008.06.010

Kooker, B.M., Shoultz, J. \& Codier, E.E., 2007, 'Identifying emotional intelligence in professional nursing practice', Journal of Professional Nursing 23(1), 30-36. $\mathrm{http}: / / \mathrm{dx}$.doi.org/10.1016/j.profnurs.2006.12.004, PMid:17292131

Matthews, G., Zeidner, M. \& Roberts, R.D., 2004, Emotional intelligence: science and myth, Massachusetts Institute of Technology, Massachusetts.

Mayer, J.D., Roberts, R.D. \& Barside, S.G., 2007, 'Human abilities: emotional intelligence', The Annual Review of Psychology 59, 507-536. http://dx.doi. org/10.1146/annurev.psych.59.103006.093646, PMid:17937602

McQueen, A.C., 2004, 'Emotional intelligence in nursing work', Journal of Advanced Nursing 47(1), 101-108. http://dx.doi.org/10.1111/j.1365-2648.2004.03069.x, PMid:15186473

Mealer, M., Jones, J. \& Moss, M., 2012, 'A qualitative study of resilience and posttraumatic stress disorder in United States ICU nurses', Intensive Care Medicine 38(9), 1445-1451. http://dx.doi.org/10.1007/s00134-012-2600-6, PMid:22618093

Morrison, J., 2008, 'The relationship between emotional intelligence competencies and preferred conflict-handling styles', Journal of Nursing Management 16(8), 974-983. http://dx.doi.org/10.1111/j.1365-2834.2008.00876.x, PMid:19094110 
Ogińska-Bulik, N., 2005, 'Emotional intelligence in the workplace: exploring its effects on occupational stress and health outcomes in human service workers', International Journal of Occupational Medicine and Environmental Health 18(2), I67-175.

Organization for Economic Co-operation and Development (OECD) (2003), Trends in International Migration 2003, viewed 29 July 2013, from http://www.oecd.org/ els/mig/31853067.pdf

Omdahl, B.L. \& O'Donnell, C., 2005, 'Emotional contagion, empathetic concern and communicative responsiveness as variables affecting nurses' stress and occupational commitment', Journal of Advanced Nursing 29(6), 1351-1359. http://dx.doi.org/10.1046/j.1365-2648.1999.01021.x

Pérez, J.C., Petrides, K.V. \& Furnham, A., 2005, 'Measuring trait emotional intelligence', in R. Schulze \& R.D Roberts (eds.), Emotional intelligence: an international handbook, pp. 123-143, Hogreefe \& Huber. Cambridge.

Petrides, K.V., 2006, 'Internal consistency data for the TEIQue and TEIQueSF (v.1.50) Trait Emotional Intelligence Research Program', viewed 07 July 2009, from http:// www.psychometriclab.com/Webnote_1.pdf

Petrides, K.V. \& Furnham, A., 2000, 'On the dimensional structure of emotional intelligence', Personality and Individual Differences 29(2), 313-320. http://dx.doi. org/10.1016/S0191-8869(99)00195-6

Petrides, K.V. \& Furnham, A., 2001, 'Trait emotional intelligence: psychometric investigation with reference to established trait taxonomies', European Journal of Personality 15(6), 425-448. http://dx.doi.org/10.1002/per.416

Petrides, K.V. \& Furnham, A., 2003, 'Trait emotional intelligence: behavioural validation in two studies of emotion, recognition and reactivity to mood induction', Europea Journal of Personality 17(1), 39-57. http://dx.doi.org/10.1002/per.466

Petrides, K.V. \& Furnham, A., 2006, 'The role of trait emotional intelligence in a gender-specific model of organizational variables', Journal of Applied Socia gender-specific model of organizational variables', Journal of Applied Social
Psychology 36(2), 552-569. http://dx.doi.org/10.1111/j.0021-9029.2006.00019.x

Petrides, K.V., Furnham, A. \& Mavroveli, S., 2007, 'Trait emotional intelligence: moving forward in the field of El', in G. Matthews, M. Zeidner \& R.D. Roberts (eds.), The science of emotional intelligence: knowns and unknowns, pp. 151-166, Oxford University Press, Oxford.

Petrides, K.V., Pita, R. \& Kokkinaki, F., 2007, 'The location of trait emotional intelligence in personality factor space', British Journal of Psychology 98(2), 273-289. http:// dx.doi.org/10.1348/000712606X120618, PMid:17456273

Pillay, R., 2007, 'A conceptual framework for the strategic analysis and management of the brain drain of African health care professionals', African Journal of Business Management 1(2), 26-33.

Pillay, R., 2009, 'Retention strategies for professional nurses in South Africa' Leadership in Health Services 22(1), 39-57. http://dx.doi.org/10.1108/17511870910928010
Polit, D.F., Beck, C.T. \& Hungler, B.P., 2001, Essentials of nursing research: methods, appraisal, and utilization, 5th edn., Lippincott, Philadelphia.

Poncet, M.C., Toullic, P., Papazian, L., Kentish-Barnes, N., Timsit, J.F., Pochard, F., et al., 2007, 'Burnout syndrome in critical care nursing staff', American Journal of rccm.200606-8060C, PMid:17110646

South African Society of Anaesthesiologists, 2006, 'Practice Guidelines 2006, viewed 29 July 2013, from http://www.sasaweb.com/images/PracticeGuidelines2006.pdf

Psychology Information Online, n.d., '404. What are personality traits or characteristics?', viewed 07 July 2009, from http://www.psychologyinfo.com/ $\mathrm{faq} / /$ problems/404.html

Republic of South Africa, 2005, The Nursing Act, 33 of 2005, Government Printer, Pretoria

Scribante, J. \& Bhagwanjee, S., 2007, 'National audit of critical care resources in South Africa - nursing profile', South African Medical Journal 97(12 Pt 3), 1315-1318.

Seekoe, E., 2010, 'Mentoring newly appointed nurse educators (NANE) in nursing education institutions', unpublished doctoral thesis, Department of Nursing Science, University of Johannesburg, Johannesburg.

Shipley, N.L., Jackson, M.J. \& Segrest, S., 2010, 'The effects of emotional intelligence, age, work experience, and academic performance', Research in Higher Education Journal (9), 1-18.

South African Nursing Council, 2009, 'Age distribution critical care nurses/midwives, age statistics', viewed 10 August 2010, from http://www.sanc.co.za/Stats/ Stat2009/Age\%20stats\%202009 files/frame.htm

Trait Emotional Intelligence Research Programme, 2001, 'TEIQue version 1.50', viewed 07 July 2009, from http://www.psychometriclab.com/admins/files/TEIQue\%20 interpretations.pdf

Towell, A.J., Nel, W.E. \& Müller, A., 2011, 'Model of emotional intelligence for the facilitation of wholeness of critical care nurses in South Africa', unpublished doctoral thesis, Department of Nursing Science, University of Johannesburg, Johannesburg.

University of Johannesburg, 2009, Paradigm: the theory for health promotion, Department of Nursing Sciences, University of Johannesburg, Johannesburg.

Vitello-Cicciu, J.M., 2002, 'Exploring emotional intelligence. Implications for nursing leaders', Journal of Nurse Administrators 32(4), 203-210. http://dx.doi. org/10.1097/00005110-200204000-00009

Vitello-Cicciu, J.M., 2003, 'Innovative leadership through emotional intelligence', Nursing Management 34(10), 28-32. http://dx.doi.org/10.1097/00006247200310000-00010, PMid:14557778 